\title{
Fabrication of Copper Oxide Thin Films by Galvanostatic Deposition from Weakly Acidic Solutions
}

\author{
Mansoureh Keikhaei , Masaya Ichimura \\ Department of Electrical and Mechanical Engineering, Nagoya Institute of Technology, Gokiso, \\ Showa, Nagoya 466-8555, Japan \\ *E-mail: keykhaei@gmail.com
}

doi: $10.20964 / 2018.10 .32$

Received: 30 May 2018 / Accepted: 11 July 2018 / Published: 1 September 2018

Copper oxide thin films are deposited low $\mathrm{pH}(<6)$ and low and high temperatures $\left(10^{\circ} \mathrm{C}\right.$ and $\left.60^{\circ} \mathrm{C}\right)$, using cathodic electrochemical deposition. The effects of the deposition current densities are studied in a range including values high enough to electrolyze water, promoting hydrogen bubbles generation. The influences of deposition variables on film composition and structural, morphological, and optical properties are investigated. Auger electron spectroscopy results indicate the fabrication of both $\mathrm{Cu}_{2} \mathrm{O}$ and $\mathrm{CuO}$, which is consistent with the results of Raman spectroscopy. $\mathrm{X}$-ray diffraction patterns show (111) and (220) peaks related to $\mathrm{Cu}_{2} \mathrm{O}$ for the samples deposited at $60^{\circ} \mathrm{C}$, whereas samples deposited at low temperatures are almost amorphous.

Keywords: electrochemical deposition, copper oxide, thin films, water electrolysis and band gap

\section{FULL TEXT}

(C) 2018 The Authors. Published by ESG (www.electrochemsci.org). This article is an open access article distributed under the terms and conditions of the Creative Commons Attribution license (http://creativecommons.org/licenses/by/4.0/). 